\title{
March on, not in
}

The production setbacks for Genzyme's rare-disease drug Fabrazyme are tragic for the people who need the medicine. But a petition to break the company's patent exclusivity could do far more harm than good.

O n 23 March, Genzyme announced that yet another batch of its Fabrazyme drug, an enzyme replacement therapy used to treat Fabry's disease, had failed to meet industry standards for manufacturing procedures. For Genzyme, it was just the latest in a long string of production setbacks since the Cambridge, Massachusetts-based biotech firm discovered a virus contaminating its manufacturing plant two years ago. For Genzyme investors, it could mean less money under the Sanofi-aventis buyout plan if the company fails to meet specified production levels in time. And for Fabry's disease sufferers-many of whom are already taking only a fraction of their usual drug regimen while supplies are low-the delay could trigger more rationing and induce more suffering.

It's a dire situation all around. Yet the legal tactic employed by some patients with Fabry's disease two weeks later-although well meaning in its intent to boost Fabrazyme supplies - could end up hurting people with this disease more than helping their cause. And, in so doing, the action could damage the US drug industry and, ultimately, health care as a whole.

On 5 April, for the second time in less than a year, a group of people with Fabry's disease, a rare lysosomal storage disorder, petitioned the US National Institutes of Health (NIH) to override Genzyme's patent rights and license the intellectual property surrounding Fabrazyme to other drug manufacturers. Such a move is permitted under the Bayh-Dole Act of 1980, which gave universities and small businesses that use government funds control of their inventions but enabled funding agencies to 'march in' and license patents to third parties when contractors fail to satisfy the health and safety needs of the public. The provision, however, has rarely been tested. Prior to the first Fabrazyme petition, over the past three decades the government has only reviewed three of these march-in requests and has not granted any of them. But as discussed on page 522, this petition seems different.

If ever there was a textbook case for using march-in rights, this would be it. A group of patients needs a life-saving drug that was developed using taxpayer dollars at Mt. Sinai School of Medicine, yet the drug's sole contract holder can't seem to deliver on time. When the $\mathrm{NIH}$ rejected the first petition from the Fabry's group in December, the agency cited Genzyme's promises to be back to full production of Fabrazyme by early 2011. But early 2011 has come and gone, and who's to say there won't be more delays to Genzyme's latest forecasts? Thus, a compelling argument can be made that it's time to allow other manufacturers to step in to expedite production of the drug. However, such a move could have the opposite effect.

For starters, any competitor on the market probably couldn't produce Fabrazyme fast enough to make a difference. As with any biosimilar agent, working out the specifics of manufacturing would probably take at least two years, and the regulatory review process could add another. The petitioners asked specifically that Genzyme hand over its cell line, but considering that a march-in order would compel the company to release only the patents on Fabrazyme and not all the surrounding protocols and technology, another two years could easily be needed, suggesting that the therapy would become available five years from now at the earliest.

Genzyme, however, should be up and running much sooner-and they continue to spend millions of dollars in plant repairs to get there. But if the NIH chooses to exercise its march-in muscle and strip the company of its patent exclusivity, Genzyme might be dissuaded from bothering to fix its problems and abandon its Fabrazyme development altogether. Such a move would leave patients in the lurch for far longer than the two years they've waited so far.

Looking beyond this particular incident, a precedent-setting march-in could also have far-reaching ripple effects for the entire pharmaceutical industry. If any unexpected production woe is perceived as a threat to patent rights and, thus, profitability, drug companies might simply steer clear of academic-driven intellectual property, particularly in the arena of biologic drugs for rare diseases. Marching in could ultimately undermine the intent of the very same legislation that granted the NIH the power to do so.

Noting that the march-in measure is an imperfect solution, some parties-including the petitioners with Fabry's disease-have called for a more hands-on approach from the US Food and Drug Administration (FDA) at the first signs of any drug shortages. The FDA could help prevent situations like the one affecting patients with Fabry's by making approval of a biologic contingent on the existence of back-up plans. With a little foresight, production problems should not have to derail drug supplies for such a lengthy period of time.

Perhaps the biggest problem with the Genzyme plant cleanup is that the company has been reactionary and ill prepared for dealing with the stumbling blocks along the way. Yet the legal action proposed by the Fabry's petition is an equally reactionary move. Messing with intellectual property rights, however well intentioned, will cause only more problems. 